\title{
THE BOOK OF JUDITH IN THE WORKS OF CLEMENT OF ALEXANDRIA AND ORIGEN
}

\begin{abstract}
The biblical book of Judith, a product of Jewish culture, belongs to the Greek canon of the Septuagint. The present study focuses on early interpretations of this book in the Eastern Christian tradition, particularly in the works of Clement of Alexandria and Origen. Through occasional quotations, both show how creatively and wisely Eastern Christianity of the second and third centuries $\mathrm{CE}$ understood the figure of this biblical, unique heroine.
\end{abstract}

Keywords: book of Judith, fathers of the Church, Clement of Alexandria, Origen, history of biblical interpretation

\section{KSIĘGA JUDYTY W DZIEŁACH KLEMENSA Z ALEKSANDRII I ORYGENESA}

\section{Streszczenie}

Biblijna księga Judyty, będąca wytworem kultury żydowskiej, należy do greckiego kanonu Septuaginty. Niniejsze studium koncentruje się na wczesnych interpretacjach tej książki w tradycji wschodniego chrześcijaństwa, zwłaszcza w dziełach Klemensa z Aleksandrii i Orygenesa. Obydwa dzieła pokazują, jak twórczo i mądrze chrześcijaństwo wschodnie w drugim i trzecim wieku n.e. rozumiało postać tej tak wyjątkowej biblijnej bohaterki.

Słowa kluczowe: księga Judyty, ojcowie Kościoła, Klemens z Aleksandrii, Orygenes, historia interpretacji biblijnej

1 Fr. dr Dionisio Candido, PhD in Biblical Sciences and PhD in Theology, Post-Doc in Textual Criticism of the Bible at the Theological Faculty of the University of Salzburg, Full Professor of Biblical Exegesis at Istituto Superiore di Scienze Religiose, Siracusa (Italy) and Visiting Professor of Methodology and Textual Criticism of the Old Testament at Studium Biblicum Franciscanum, Jerusalem (Israel); ORCID: 0000-0001-7074-9912, e-mail: nisi. candido@email.it. 


\section{Introduction}

The biblical book of Judith is titled after the main character and heroine of the story: during the siege of her town by the Assyrians, she manages to enter the enemy camp, to gain the trust of commander Holofernes, and, finally, to kill him, an act that leaves the Assyrian army dazed without its leader and ultimately defeated by the Israelites.

An initial question for scholars concerns the language and textual tradition of this biblical book. Although the story was written for a Jewish audience, it is known only in the Greek textual form: no ancient Hebrew (or Aramaic) text has come down to us ${ }^{2}$. There is no trace of it neither among the Dead Sea Scrolls, nor among the works of Flavius Josephus and and the rabbis (Mishnah or Talmud). The latter will only take up interest in the story of Judith from the century XI CE onwards, when a flowering of Hebrew texts will begin, which are likely retroversions from Greek or Latin.

A second question concerns the interpretation of the story, especially in the Christian tradition: As the protagonist in the story, Judith proudly and consciously engages in deceit (cf. Jdt 11:5-6.18-20), seduction (cf. Jdt 10:1-4) and murder (cf. Jdt 13:1-6) ${ }^{3}$. How to reconcile such behavior with Christian ethics?

This study focuses on some of the earliest interpretations of the book of Judith in the Christian tradition, found in the works of two illustrious Fathers of the Church: Clement of Alexandria (ca. 150-215 CE) and Origen (ca. 185-254 CE). Neither dedicates himself to explicating a specific text in Judith, but both do cite this book occasionally in support of other arguments. Theirs, however, is the earliest testimony to a shared exegetical engagement with the book of Judith between Egypt and Palestine; that is, within early eastern Christianity the Old Testament was known in both Greek and Hebrew traditions. Both Clement and Origen, in fact, lived in Alexandria of Egypt where the books of the Hebrew Bible were first translated into Greek beginning in the 3rd c. BC, a translation commonly referred to as the Septuagint. The eastern Fathers therefore also knew the canon of the Hebrew Bible, in which the book of Judith, however, did not find space. The investigation into the writings of Clement and Origen allows us to understand if and how the eastern Christianity of the 2nd and 3rd c. CE has read this unparalleled book of the Old Testament.

2 Robert Hanhart, Judith, Septuaginta. Vetus Testamentum Graecum Auctoritate Academiae Scientiarum Gottingensis editum, vol. VIII/4 (Göttingen: Vandenhoeck \& Ruprecht, 1979). This critical edition is based on Codex Vaticanus, as it was for the editions of Cambridge (Alan E. Brooke and Norman McLean, The Old Testament in Greek according to the Text of the Codex Vaticanus, vol. III/1 (Esther, Judith, Tobit) (Cambridge, UK: Cambridge University Press, 1940) and of Henry Barclay Swete (Henry Barclay Swete, The Old Testament in Greek according to the Septuagint, vol. II (Ioudith) (Cambridge, UK: Cambridge University Press, $\left.\left.{ }^{3} 1907\right), 781-814\right)$. The edition of Rahlfs, afterwards revised by Hanhart, follows more closely the Codex Sinaiticus (Alfred Rahlfs, Robert Hahnart, Septuaginta. Id est Vetus Testamentum graece iuxta LXX interpretes. Editio altera (Stuttgart: Deutsche Bibelgesellschaft, 2006), spec. 973-1002). For further information on the philology and textual history of the book of Judith compare with Robert Hanhart, Text und Textgeschichte des Buches Judith, Mitteilungen des SeptuagintaUnternehmens 14 (Göttingen: Vandenhoeck \& Ruprecht, 1979).

3 Dionisio Candido, Giuditta. Nuova versione, introduzione e commento, I libri biblici. Primo Testamento 32 (Milano: Paoline, 2020), 208-216. 


\section{Clement of Alexandria}

The biography of Titus Flavius Clement (c. 150-215 CE) is still partly shrouded in mystery. He probably came from a pagan family originally from Athens, but travelled extensively, all of which he himself reports (cf. Stromata, I, 1, 11), and it is in Alexandria of Egypt where he ultimately establishes his scholastic agenda. The Alexandrian school, known for its affinity with Platonic and Neoplatonic philosophical thought and for the allegorical interpretation of Bible, will find in him a prominent proponent of this traditon.

Eusebius of Caesarea devotes significant space to Clement in the Ecclesiastical History $(\mathrm{V}, 11,1-5)^{4}$, describing him as a disciple of Panthenus, who was simply recognized as the

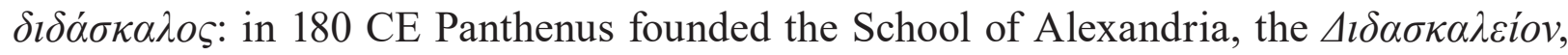
and directed it until he died around $200 \mathrm{CE}$, at which time Clement succeeded him (Stromata, I, 11, 2); Origen then succeeded Clement.

Clement's theology and biblical interpretation interact closely with Greek philosophy or, even better, with Hellenistic philosophy. In particular, inspired by the exegesis of Philo of Alexandria (ca. $20 \mathrm{BC}-45 \mathrm{CE})^{5}$, Clement gives life to a hermeneutic of the Scriptures in which allegory is dominant.

\subsection{Stromata, II}

With the title Stromati ( $\Sigma \tau \rho \omega \mu \alpha \tau \varepsilon \tilde{\varsigma} \varsigma)$, lit. "carpets", "tapestry", Clement indicates a work on various topics and without the concern for systematicity (cf. Stromata, VI, 1, 2, 1). His main agenda in the work is to almalgamate Christian faith with Greek philosophy, so in addition to the numerous citations of authors of classical Greekism, Stromata contains more than five thousand quotations from the Bible ${ }^{6}$. Clement specifically recalls the biblical character of Judith in two passages, II, 7 and IV, 8.

In Stromata II, 7 Clement is concerned with, among other things, the importance

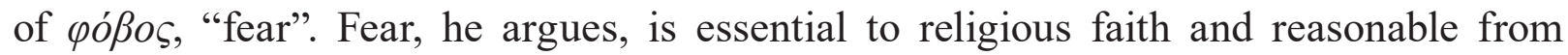
a philosophical point of view because it is a prelude to the respect for divine law: fear is pedagogical, because it educates the believer in the observance of divine precepts. Clement makes his case by quoting Pro 1:7 with the following comment: "The principle

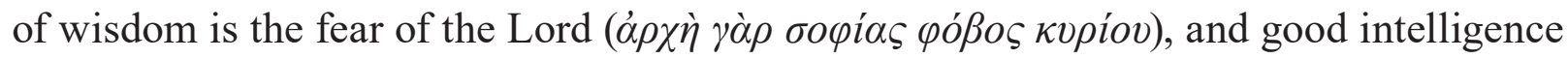
for those who practice it". The law is capable of generating fear: therefore knowledge of

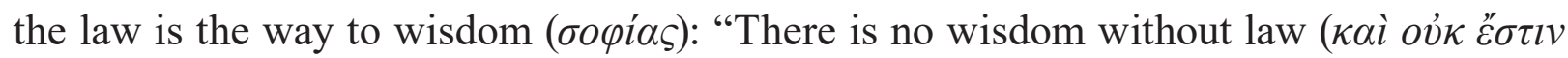

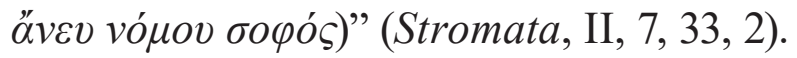

In contrast, Clement states that "those who despise the law are fools; and consequently they are considered atheists $(\ddot{\alpha} \theta \varepsilon o l) "$ (Stromata, II, 7, 33, 3). Clement continues by

4 Eusèbe de Césarée, Histoire Ecclésiastique, ed. Gustave Bardy, vol. I, Sources Chrétiennes 31 (Paris: Cerf, $\left.{ }^{31} 1993\right)$, 40-41.

5 In the nineteen essays of his allegorical Commentary on the Bible, Philo never mentions the book of Judith.

6 To be exact, it is 5.121, according to Marco Rizzi, "Introduzione", in: Clemente di Alessandria, Gli Stromati. Note di vera filosofia (Milano: Paoline, 2006), IX. 
affirming that the law is like a $\pi \alpha l \delta \alpha \gamma \omega \gamma o$ s, which leads to Christ (cf. Gal 3:24). Fear distracts from evil and encourages towards good. For the Lord does not want the death of the sinner, but that the sinner should desist from his ungodly behavior and resume life (cf. Ezek 33:11). It is therefore wrong to think that fear leads to death. Clement then inserts an allusion to the book of Judith when he writes": "He who is close to the Lord

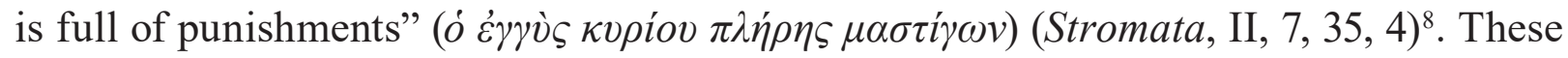
words are more a paraphrase or allusion than a literal quotation, since the text of Jdt 8:27 reads: "Well, as he purified these to try their hearts, so he punished us: but the Lord

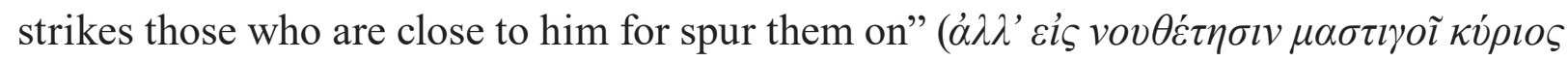

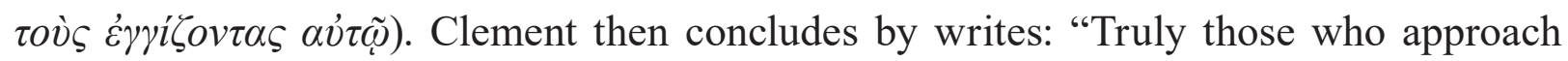
knowledge suffer dangers, fears, adversities, afflictions, because of their desire for truth".

Judith is evoked in Stromata II, 7 as an example of a proven faith. But Clement bends the biblical text to his purpose by means of allegory. The text used is in fact extrapolated from the broader context of Judith's speech to the elders of the people in Jdt 8:9-27. Here Judith enters decisively into the quarrel with the leaders of the town of Bethulia regarding the strategy to be adopted in the current crisis (Jdt 8:9-10). The scenario that frames Judith's speech is missing in Clement's work, but he nevertheless uses it because of the proximity to the theme of divine testing, to which the Christian, too, is subjected.

\subsection{Stromata, IV}

Further on, in IV, 8, Clement explains at length and with unequivocal language that both men and women are called to be virtuous: "It is therefore demonstrated that, with regard to human characteristics, woman has no nature ( $\varphi v ́ \sigma \iota \varsigma)$ different from man, but the same; therefore she will also have [her] virtue ( $\dot{\alpha} \rho \varepsilon \tau \dot{\eta})$. If man's own virtues are temperance and

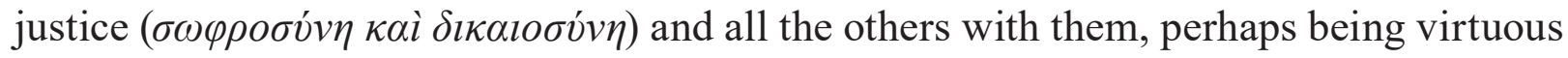
is only of the virtuous man, while the woman is intemperate and unjust? To say such a thing would be improper" (Stromata, IV, 8, 59).

Despite their diversity, woman and man are both human beings called to follow virtue $(\dot{\alpha} \rho \varepsilon \tau \dot{\eta})$. The question of who is virtuous is then taken up in IV 19 and 20; here Clement supplies a list of exemplary figures, especially women, both from the Scriptures and from pagan Greek literature. Here Clement urges his readers to praise these men and women of the Bible because they have provided proof of that perfection of which he had previously spoken (Stromata, IV, 19, 118) ${ }^{9}$.

Undoubtedly the first to remember is Moses, who had continued to intercede on behalf of God's people even when they had succumbed to the sin of idolatry with the golden calf (Ex 32:1-34.35). Judith, too, was a mediator like Moses between God and the people,

7 An analogous expression in Job 5:17-18: "Happy is the man whom God reproves! The Almighty's chastening do not reject. For he wounds, but he binds up; he smites, but his hands give healing” (NASB).

8 Patrologia Graeca 8,969.

9 Clément d'Alexandrie, Le Stromates IV, ed. Anneweis van den Hoek, Sources Chrétiennes 463 (Paris: Cerf, 2001), $252-254$. 
putting herself in harm's way for the sake her people. Clement states: "Even Judith, who became perfect among women ( $\dot{\varepsilon} v$ $\gamma v v \alpha l \xi i$ $\tau \varepsilon \lambda \varepsilon l \omega \theta \varepsilon \tilde{\varepsilon} \sigma \alpha)$ during the siege of the city, faced with the pleading of the elders, advances towards the camp of foreigners, despising every danger for the good of the nation, she offers herself to the enemies trusting in God ( $\dot{\varepsilon} v$ $\pi i \sigma \tau \varepsilon l \theta \varepsilon o \tilde{v})$, she soon accomplishes the feat, a woman distinguished by faith $(\tau \tilde{\eta} \varsigma \pi i \sigma \tau \varepsilon \omega \varsigma$ $\dot{\alpha} \rho \imath \tau \tau \varepsilon \dot{v} \sigma \alpha \sigma \alpha \gamma v v \dot{\eta})$, against the enemy of faith and conquers the head of Holofernes". The term $\tau \varepsilon \lambda \varepsilon \iota \omega \theta \varepsilon \tilde{\imath} \sigma \alpha$, "made perfect", reverberates with the Letter to the Hebrews, where it is used about Jesus: "Although he was a Son, he learned obedience from what he suffered and, made perfect ( $\tau \varepsilon \lambda \varepsilon i \omega \theta \varepsilon i \varsigma)$, he became the cause of eternal salvation for all who obey him" (Heb 5:8-9).

In addition to the figure of Judith, Clement includes other illustrious female figures from the Old Testament: Esther, "the perfect in faith" ( $\dot{\eta} \tau \varepsilon \lambda \varepsilon i \alpha \kappa \alpha \tau \dot{\alpha} \pi i \sigma \tau \imath v)$, is the first to be united with Judith for her commitment to the salvation of the people, as she herself says in her prayer (Esth C:12-30, according to the LXX version). Then Clement refers to Susanna, a character from the Greek version of Daniel (Dan 13:1-64, according to the version of the LXX): she has not renounced her moral integrity, even in the face of the danger of losing her life, and for this reason she is to be considered an "unshakable

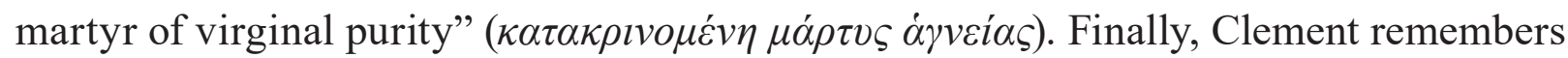
Miriam, the sister of Moses, who after the passage of the Red Sea guides the women of Israel in a song of victory: "Being she who leads with wisdom the praiseworthy women

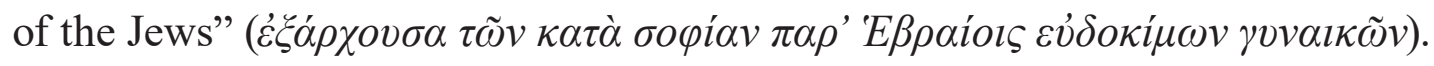

The common denominator among Judith and the other women is the virtue of intrepid courage in the name of righteousness for the salvation of Israel. Clement then emblematically concludes the chapter by arguing that one should apply oneself with self-discipline to the virtues, like the exemplary figures his lists from the Old Testament: "Neither man nor woman can do anything without education, exercise and commitment ( $\mu \grave{\eta} \mu \alpha \theta \dot{\eta} \sigma \varepsilon \imath$

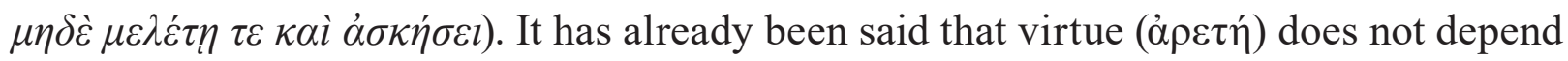
on others but above all on ourselves" (Stromata, IV, 19, 124).

Clement therefore gives us an extraordinary lesson in biblical anthropology on "virtue" $(\dot{\alpha} \rho \varepsilon \tau \dot{\eta})$ by re-reading female biblical figures such as Judith, and an instructive example of his extraordinary ability to investigate the biblical text and dialogue with pagan culture.

\section{Origen}

The intellectual and ethical stature of Origen (ca. 185-254 CE) undoubtedly went beyond the borders of the early eastern Christianity. His biography is essentially divided between Alexandria in Egypt (185-232 CE) and Caesarea in Palestine (232-254 CE). In Alexandria, his hometown, he experiences the tragic death of his father Leonidas, martyred around the year $202 \mathrm{CE}$ during one of the persecutions of Roman emperor Septimius Severus (193-211 CE). Then in $203 \mathrm{CE}$, when he is still only eighteen years old, his extraordinary genius allow him to become the director of $\Delta \imath \delta \alpha \sigma \kappa \alpha \lambda \varepsilon i o v$, succeeding Clement; he will 
hold this office until $231 \mathrm{CE}$. The following year, having been forcibly moved to Caesarea in Palestine, he founded a new school with the support of bishop Theoctistus, who also ordained him a priest.

His works, which range between Bible and theology, is substantial: from exegetical works, such as the philological masterpiece the Hexapla, to theological treatises, polemic writings, and other occasional writings.

\subsection{The Prayer}

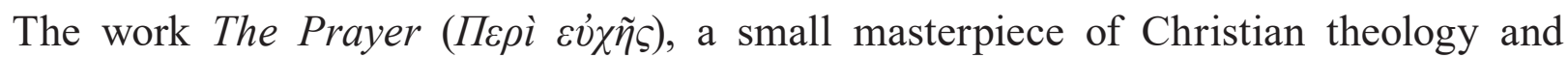
spirituality, dates back to around 233-234 CE, that is, at the beginning of the period of residence in Caesarea, when Origen had already been ordained a priest. Although it is dedicated to a specific issue, it is a truly accurate treatise on theology and spirituality. Not surprisingly, due to its content and the manner of its treatment it will have a notable echo in the Christianity of the centuries to come.

After the prologue (chs. 1-2), Origen illustrates in the first part (chs. 3-17) the importance of prayer itself, defending it in front of possible opponents. In the second part (chs. 18-30) he provides a detailed commentary on the Our Father ${ }^{10}$. Finally, in the last part (chs. 31-33), as an appendix, Origen offers some practical suggestions for prayer.

Within this work, Origen mentions the book of Judith five times. The first time is to affirm that Scripture is full of examples of prayers: "But what need is there to enumerate those who, by praying properly, obtained the greatest graces from God, each being able to choose several examples from the Scriptures? Anna obtained the birth of Samuel who was counted with Moses; as she had no children, she believed and prayed to the Lord; Hezekiah, childless, and learned from Isaiah that he was going to die, prayed and was included in the Savior's genealogy. By now the people were about to succumb under a single edict, the fruit of Haman's snares: but having heard the prayer and fasting of Mordecai and Esther, as well as the feast of Moses, they procured for the people 'a day of Mordecai's joy'. And also Judith, having addressed a holy prayer ( $\dot{\alpha} \gamma i \alpha v \dot{\alpha} v \varepsilon v \varepsilon \gamma \kappa o \tilde{v} \sigma \alpha$ $\pi \rho o \sigma \varepsilon v \chi \grave{\eta} v)$, with the help of God ( $\mu \varepsilon \tau \dot{\alpha} \theta \varepsilon o \tilde{v})$ won Holofernes, and a single Jewish woman marked the house of Nebuchadnezzar with a stigma" (Prayer 13, 2$)^{11}$.

Origen intends to demonstrate the effectiveness of prayer. Thus Anna, mother of Samuel (cf. 1 Sam 1:1-2:10), King Hezekiah (cf. Isa 38:1-21), Mordecai and Esther (Esth C:9-10 according to LXX) are cited for their respective biblical prayers, which the Lord did not fail to hear. Regarding Judith's prayer, Origen states that she alone managed to overcome the fearsome Assyrian army through her "holy prayer" ( $\dot{\alpha} \gamma i \alpha v$ (...) $\pi \rho o \sigma \varepsilon v \chi \eta \dot{v})$.

10 On the allegory adopted by Origen in the interpretation of sacred scripture and its effects in the history of interpretation, see the two articles by Henri De Lubac, “"Origene» e «Posterità origeniana»", in: Esegesi medievale. I quattro sensi della Scrittura. Parte prima, Volume primo, Sezione quinta: Scrittura ed Eucaristia, Opera omnia 17 (Milano: Jaca Book, $\left.{ }^{2} 2006\right), 209-232$.

11 Patrologia Graeca 11,454. Origene, La preghiera, ed. Normando Antoniono, Testi Patristici 138 (Roma: Roma, $\left.{ }^{4} 2008\right), 74$. 
In doing so, he exalts Judith making her an exemplary figure because of her prayer (cf. Jdt 9:1-14); in doing so, he also resolves any doubts about her virtue that may have been raised by the biblical text. Origen states: "On the other hand, how many enemies were not killed, even though they fought us with an immense number of hostile forces and wanted to detach ourselves from faith in God! Having trusted "these in the chariots, those in the horses, but we in the name of the Lord" (Psa 19:8), while praying we see that "indeed the horse is wrong to save" (Psa 32:17). He who has trusted in praise to God - in fact Judith

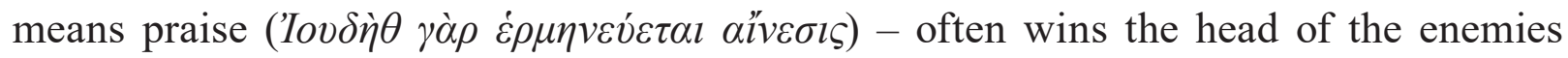
symbolized in the deceptive and persuasive word that throws terror even among those who were believed to have faith" (Prayer 13, 3). ${ }^{12}$

Using parenetic language, Origen intends to encourage believers who come up against the adversities of life. In this context, the explanation of her name - "Judith means praise"

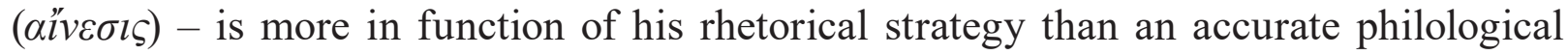
assessment. Her name in fact recalls "Judea", but it is also true that the book ends with a hymn of praise sung by Judith to the Savior God of Israel (Jdt 16:1-17).

The following lines once again mentions Judith: "We must in fact take care that our

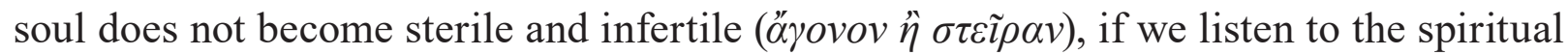

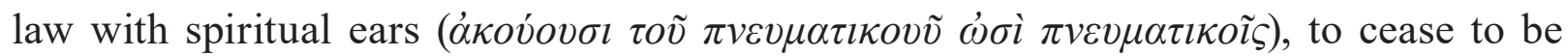
sterile and infertile and to be heard like Anna and Hezekiah; and so that we may be freed like Mordecai, Esther and Judith from the wickedness of the spiritual enemies who threaten us" (Prayer, 13, 4) $)^{13}$.

Origen recalled the need for the person praying to live according to the spirit and not according to the flesh (cf. 2 Cor 10:3; Rom 8:13). He then cites the same biblical characters previously mentioned (Prayer 13, 2): Anna, Hezekiah, Mordecai, Esther and Judith. The list of names of famous people is a frequent literary genre not only in the work of Origen, and one can imagine that it served a necessary purpose in preaching ${ }^{14}$. Of the first two, he states that prayer provided the impetus for God to heal them of sterility and infertility; of the latter three, he states that their prayers of thanksgiving yielded them victory over "the spiritual enemies who set snares for us" ( $\dot{\alpha} \pi \dot{o} \varepsilon \dot{\varepsilon} \pi \beta o v \lambda \varepsilon v o ́ v \tau \omega v \dot{\varepsilon} \chi \theta \rho \tilde{\omega} v \tau \tilde{\omega} v \pi v \varepsilon v \mu \alpha \tau \imath \kappa \tilde{\omega} v)$.

Here Origen's interpretation is not only typological, but also partly allegorical. Such a tendency towards the spiritualization of the biblical characters mentioned above and their stories is even more evident in the following passage: "The soul of Anna $(\dot{\eta} \tau \tilde{\eta} \varsigma$

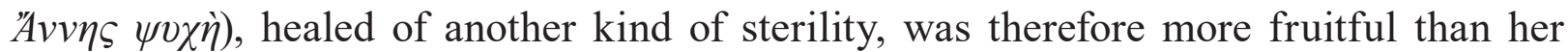

12 Origenes, Buch V-VIII gegen Celsus. Die Schrift vom Gebet, ed. Paul Koetschau, GCS 3 (Leipzig: J.C. Hinrich, 1899), 327. Origene, La preghiera, 75.

13 Patrologia Graeca 11,456. Origene, La preghiera, 76.

14 "Le figure degli oranti veterotestamentari vengono ad occupare un posto centrale nella serie di argomenti addotti dall'Alessandrino a conferma dell'utilità della preghiera e della necessità della sua pratica. Egli riunisce le diverse figure, per ben quattro volte di seguito (Orat XIII, 2; XIII, 3; XIII, 4; XVI, 3), entro un «catalogo» che, nella sua articolazione più ampia, comprende i seguenti personaggi biblici: Anna (1 Sam 1, 9-13; 2, 1-10); Ezechia (Is 38); Mardocheo e Ester (Est 4, 17a-z LXX); Giuditta (Gdt 13, 4-5); i tre giovani ebrei Anania, Azaria e Misaele (Dn 3, 24 ss. LXX); Daniele (Dn 6, 11); Giona (Gio 2); Samuele (1 Sam 12, 16-18); Elia (1 Re 17-18)" (Lorenzo Perrone, La preghiera secondo Origene. L'impossibilità donata (Brescia: Morcelliana, 2011), 143-144). 
body, which conceived Samuel ( $\tau \grave{o} \sigma \tilde{\omega} \mu \alpha, \kappa v \tilde{\eta} \sigma \alpha \nu \tau \grave{\nu} v \Sigma \alpha \mu o v \dot{\eta} \lambda)$; Hezekiah bore children

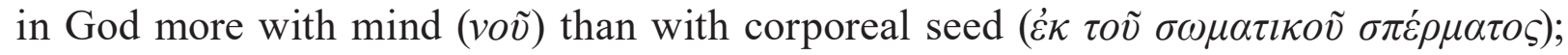
Esther and Mordecai and the people were freed from spiritual snares far more than from those of Haman and his conspirators; Judith destroyed more the strength of the prince, who wanted to kill his soul, than that of the famous Holofernes ( $\tau$ vo $\delta \imath \alpha \varphi \theta \varepsilon \tilde{\imath} \rho \alpha \imath \tau \grave{\eta} v \psi v \chi \grave{\eta} v$

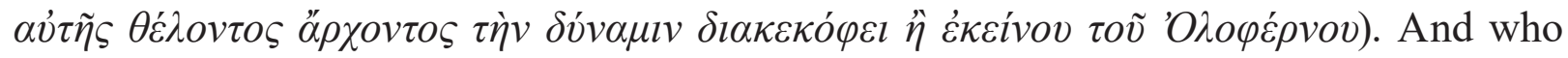
would not confess that on Ananias and his companions the spiritual blessing that reaches all the saints - that of which Isaac speaks to Jacob: "God give you dew from heaven" (Gen 27:28) - has come down in a more abundant way of the material dew that extinguished Nebuchadnezzar's flame? And invisible lions who could no longer affect his soul in any way did not shut their mouths before the prophet Daniel much more than the real lions we all know from reading Scripture? And who managed to escape the belly of the monster, tamed by Jesus our Savior, who devours God's deserters, as well as Jonah, who became capable of receiving, as a holy man, the Holy Spirit?" (Prayer, 16, 3) $)^{15}$.

Origin states immediately that Anna's "soul" ( $\dot{\eta} \psi v \chi \dot{\eta})$ has a greater importance than her "body" $(\sigma \tilde{\omega} \mu \alpha)$. Regarding Hezekiah, he is even more poignant: "He bore children in God more with his mind than with bodily seed". On the same line of spiritualization we continue citing Esther and Mordecai (cf. Esth C:1-30), as well as Ananias, Azarias and Misael (cf. Dan 3), Daniel (cf. Dan 6:2-29) and Jonah (cf. Jonah 2:2-10): all winners thanks to prayer. This is one of the solutions that Origen adopts to integrate the value of prayer from the Old Testament into Christian spirituality: he uses these biblical examples of prayers, whose real historicity was undisputed, to then move on to an allegorical level of meaning ${ }^{16}$.

He also reserves a similar treatment for Judith: "He destroyed more the strength of the prince who wanted to kill his soul than that of the famous Holofernes". In other words, Origen believes that Judith's true victory was not accomplished only on a material level against Holofernes, but rather on a spiritual level against the one who wanted to conquer his soul. The reasoning proceeds towards an ever more pronounced spiritualization and comes to configure prayer as the believer's struggle against the spirit of evil.

Origen quotes Judith in another comment on the Our Father: "What therefore means the Savior's command to pray not to lead us into temptation $(\varepsilon \dot{v} \chi \varepsilon \sigma \theta \alpha l \mu \grave{\eta} \varepsilon \dot{i} \sigma \varepsilon \lambda \theta \varepsilon \tilde{\imath} \mathcal{v} \varepsilon \dot{i} \varsigma$

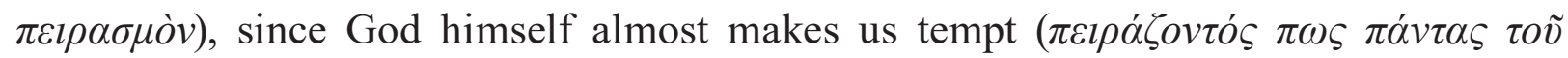
$\theta \varepsilon o \tilde{v})$ ? In fact Judith says, addressing not only the elders of her people, but to all those who would have read these words ( $\pi \rho \grave{s} \varsigma \pi \dot{\alpha} v \tau \alpha \varsigma$ $\tau o \grave{s} \varsigma \dot{\varepsilon} v \tau v \gamma \chi \alpha \dot{\alpha} v o v \tau \alpha \varsigma \alpha \dot{\tau} \tau \tilde{\eta} \varsigma \tau \tilde{\eta} \gamma \rho \alpha \varphi \tilde{\eta})$ : 'Remember what he did with Abraham and what Isaac tried and everything that happened to Jacob who grazed the flock of Laban, his mother's brother, in Mesopotamia of Syria; since he - the Lord - who scourges those who come to him to make amends will not punish us as he purified them to prove their hearts' (Jdt 8:22-27). Even David, when he

15 Patrologia Graeca 11,469. Origene, La preghiera, 89-90.

16 Maria-Barbara von Stritzky, "Die Theologie des Gebets", in: Origenes, Über das Gebet, Origenes Werke mit deutscher Übersetzung 21 (Berlin-Boston-Freiburg-Basel-Wien: De Gruyter-Herder, 2014), 36. 
says: 'Many are the afflictions of the righteous' (Psa 33:20), confirms that this is true for all the righteous. The Apostle, in turn, says in Acts 'because through many tribulations we must enter the kingdom of God' (Acts 14:22)" (Prayer, 29, 3) ${ }^{17}$.

As a good philologist, as well as a fine theologian, Origen ponders the meaning of the request addressed to the Father, "not to lead us into temptation": he in fact knows that both in the Old and New Testaments God clearly tempts believers. In this regard, before citing the Psalms and the Acts of the Apostles, he decides to quote a passage from the speech that Judith addresses the leaders of Bethulia (Jdt 8:9-36). As Clement had already done in Stromata (cf. II, 7, 35, 4), Origen uses the words of Judith to exhort believers of all times to stand firm in the trial and to trust in God's saving work.

\subsection{Commentary on the Gospel of John}

Origen was likely to have been the first author who commented on the biblical books in their entirety ${ }^{18}$. The final draft of his Commentary on the Gospel of John dates to around $235 \mathrm{CE}$, and in it he deals with both textual and exegetical questions with outstanding expertise. Only two passages seem to be taken from the book of Judith.

The first fleeting reference is part of his commentary on the words found in John 1:4: "Life was the light of men". In his opinion, this should not be understood in restrictive sense. In fact, even the expression "God of Abraham, of Isaac and of Jacob" (cf. Ex 3:16; 4:5; Acts 3:13) does not exclude that elsewhere God is a father figure to other characters: "He is also God of Elijah, - as Judith says - of his father Simeon, and God of the Jews" (Commentary on the Gospel of John, II, 22, 143). In this case, Jdt 9:2 is quoted, which contains the beginning of the prayer in Jdt 9:1-14: there the heroine addresses God before carrying out her feat and killing Holofernes. But in Origen's commentary any reference to that episode is lost.

The second reference to Judith is found in the commentary on John 4:26-27, within the account of Jesus' encounter with the Samaritan woman. Origen notes that the disciples are amazed that the Son of God talks to a woman. A little further on (Commentary on the Gospel of John, XIII, 28, 171) he argues that the disciples must have been amazed by the fact that the divine Logos lowered himself to a human soul ( $\psi v \chi \tilde{\eta})$. This allows him to claim that the disciples of that time, as with the believers of today, easily forget the true identity of God, revealed in scripture: "We do not remember the one who forms in the womb [cf. Jer 1:5] and who forms each human heart. and who knows all their works [cf. Ps 32:15]. We do not take into account that he is the God of

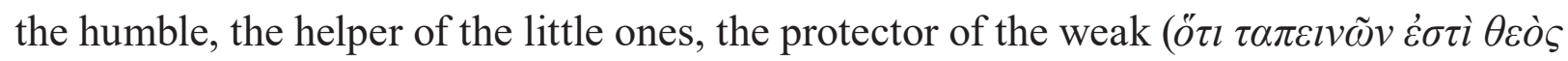

17 Patrologia Graeca 11,257 (C-D), col. 552. Origene, La preghiera, 158-159.

18 Manlio Simonetti, Lettera e/o allegoria. Un contributo alla storia dell'esegesi patristica, Studia Ephemeridis

"Augustinianum" 23 (Roma: Institutum Patristicum "Augustinianum", 1985), 74. 


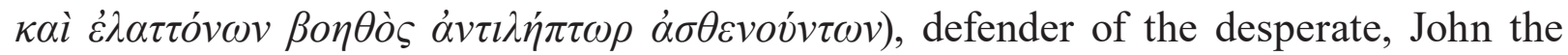
defender of the desperate ones" (Commentary on the Gospel of John, XIII, 28, 168) ${ }^{19}$.

The expression "the God of the humble, the helper of the little ones, the protector of the weak" is taken verbatim from Jdt 9:11. Origen makes the most of this text, even though it is completely decontextualized from the prayer of Judith (Jdt 9:1-14). One can say, therefore, that while on the one hand Origen shows once again that he knows and appreciates the book of Judith, on the other hand, he relies on the biblical work for purposes other than a close and precise commentary.

\subsection{Homily on Jeremiah $X X$}

From a chronological point of view, the Homilies on the book of Jeremiah date back to around $242 \mathrm{CE}$. They are the only ones that have come to us in the original Greek ${ }^{20}$. In particular, the Homily on Jeremiah $X X$ can be considered a true masterpiece of a original exegete and spiritual teacher. Origen's commentary on the expression of Jer 20:7 is particularly profound and wise: "You seduced me, Lord, and I let myself be seduced".

Origen immediately sets out his key to interpreting the passage: "Everything that is written about God, even if it were in itself absurd, must be considered worthy of a good God" (Homily on Jeremiah XX, 1). The Bible often attributes feelings such as anger or repentance to God; but these must be integrated into the overall profile of the biblical God. The same is true for the theme of seduction: "We must hold that God's seduction is of a different nature from our seduction" (Homily on Jeremiah XX, 2).

In other words, Origen invites us to go beyond the surface of words: the certainty that God wants the good of his people must be reconciled with the stories that reveal his most disturbing feelings. In reality, God behaves as a father does towards a son who is still too young to understand, or as a doctor towards his resistant or ignorant patient. He deceives out of love (cf. Homily on Jeremiah XX, 3). With paradoxical reasoning, Origen then proposes some examples from the Bibl, in which deception was advantageous for the victims. The main idea is that it is God himself who seduces and not an evil character. In this case, one can gladly accept even being deceived: "Being convinced that it is God

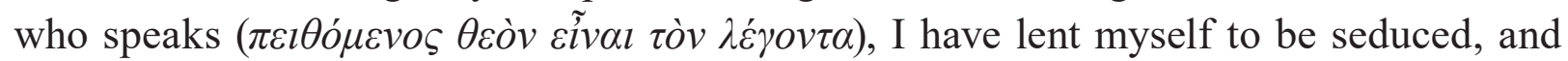
for this I say not only that you have done everything to seduce me, but that I let myself be seduced by you: for this I say you seduced me, Lord, and I was seduced" (Homily on Jeremiah $X X, 4)$.

Then Origen comments on Jer 20:8, focusing on the prophet's cry: "I will invoke infi-

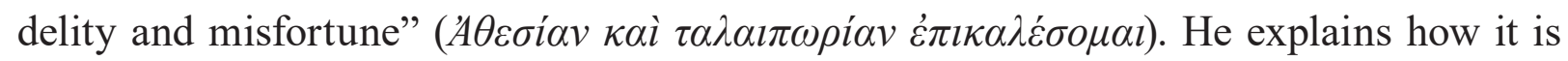
possible for a prophet of the caliber of Jeremiah, a true man of God, to invoke "infidelity"

19 Origene, Commento al Vangelo di Giovanni, ed. Vito Limone, Il Pensiero Occidentale (Milano: Bompiani, Milano, 22013), 743.

20 Together with the Homily on 1 Sam 28:3-25, the episode of the meeting between Saul and the fortune teller of Endor. The remaining homilies have come down to us through the translation of Rufinus or Jerome (ca. 342/347-420 CE). 
$(\dot{\alpha} \theta \varepsilon \sigma i \alpha)$. He wonders whether it is plausible for a believer to be unfaithful or to break an agreement: the answer is yes, if the pact is wicked and would lead to perdition. In this regard he cites the relationship between Judith and Holofernes: "I would like to give an example, taken from Scripture, of a just lack of fidelity to a pact, to show how he invoked an infidelity in action. Judith made a pact with Holofernes, according to which for a certain number of days she would go out to pray to God and after these days she would lie with Holofernes. Holofernes accepted the pact. He granted Judith prayers outside the camp. What did Judith have to do? Respect the agreements or break them? It is agreed that he should not observe them: in fact, not keeping faith with the pacts entered into with

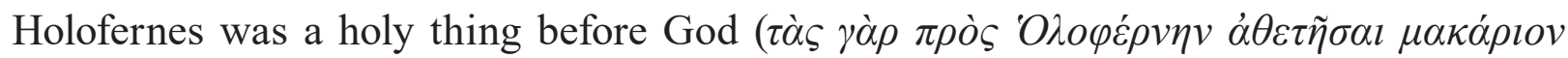
$\tilde{\eta} v \dot{\varepsilon} \pi \grave{i} \theta \varepsilon o \tilde{v})$. Judith was not faithful to the pact with Holofernes and said: I will invoke

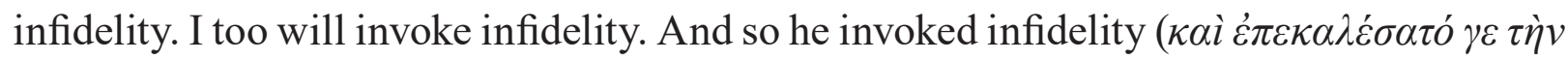
$\dot{\alpha} \theta \varepsilon \sigma i \alpha v)$. I too would have an advantage if I said I will invoke infidelity: and in fact I will invoke infidelity towards the serpent and towards the devil. When the snake made a pact with Eve, she became his friend and the snake the woman's friend; but God, because $\mathrm{He}$ is good, managed to dissolve this covenant and to dispel this perverse friendship. Also, since he is a good God, he says: I will put enmity between you and the woman, between your offspring and her offspring. Let us therefore listen with a happy heart to how God places enmity between her and him, so that she may make friends with Christ. Indeed,

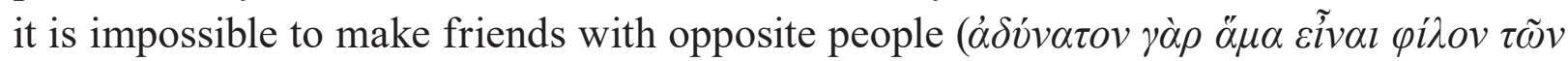
$\varepsilon v \alpha v \tau i(\omega v)$ : just as no one can serve two masters, so no one can be a friend of God and Mammon, a friend of Christ and the serpent. Rather, it is inevitable that friendship with

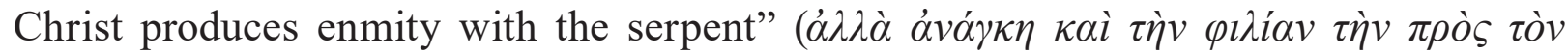
X

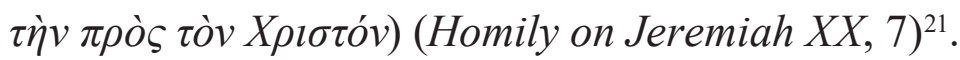

The theme of God's seduction ${ }^{22}$ as key to understanding the situations in life in which the believer feels compelled by God, has become a spiritual theme in Origen's thought. The biblical God reveals himself as the supporter of Judith, a biblical protagonist that actively deceives. Origen goes so far as to label that transgression as a blessed gesture: "Not keeping faith in the pacts entered into with Holofernes was a holy thing before God"

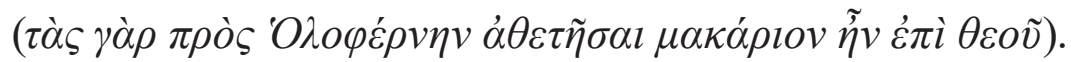

In this way, Origen clears Judith's morally questionable behavior without drawing upon allegorical methods of interpretation. The story of Judith is that of a woman who places God's saving will before any other human logic. And in this sense, both Jeremiah and Judith are exemplary for the faith of every Christian.

21 Origène, Homélies sur Jérémie. Homélies XII-XX et Homélies latines, edd. Pierre Husson, Pierre Nautin, Sources Chrétiennes 238 (Paris: Cerf, 1977), 282-284.

22 Henri De Lubac, “Tu m’a trompé”, in: Recherches dans la foi. Trois études sur Origène, saint'Anselme et la philosophie chrétienne (Paris: Beauchesne, 1979), 9-11; see also 15-21. 


\subsection{Letter to Africanus}

Among the so-called "occasional" writings one can include the letter Origen wrote to reply to another letter from the writer and scholar Sestus Julius Africanus (ca. 170-240 $\mathrm{CE}$ ). He doubted the Jewish origin of the story of Susanna, which was handed down only in the Greek version of the book of Daniel (Dan 13). Origen tackles each objection with acumen, defending the canonicity of that specific text, but also of other texts exclusively found in the Greek version of the Old Testament ${ }^{23}$, as an integral part of the Scriptures considered sacred by Christians.

In this regard he recalls the book of Judith: "We must admit that the Jews use neither Tobias nor Judith. In fact, they do not have it in Hebrew ( $\dot{\varepsilon} \beta \rho \ddot{i} \sigma \tau i)$, not even among the apocryphals ( $\kappa \hat{\alpha} v \mathcal{\varepsilon} v \dot{\alpha} \pi o \kappa \rho \dot{\varphi} \varphi o r \varsigma$ ), as we have ascertained from them" (Letter to Africanus, $19,13)^{24}$. His clarification concerns the fact that the Jews do not recognize either the book of Tobit or that of Judith.

Incidentally, in his Ecclesiastical History (VI, 25), Eusebius of Caesarea transcribes what Origen would have written in his Commentary on Psalm 1. Here he would write down the names of the twenty-two books that made up the canon of the Hebrew Sacred Scriptures, which do not obviously count the book of Judith. On the basis of what Eusebius says, Origen was describing the position of the Jews, not that of the Christians. However, this data is important because it shows the awareness of the Fathers of the Church in Palestine on the discrepancy between the Hebrew Bible and the Christian Old Testament.

However, the very statement of Origen in the Letter to Africanus shows by contrast that he considers the book of Judith to be important, since the Christian community already made use of $i^{25}$. Moreover, this corresponds to the position that Eusebius attributed to Origen also in Ecclesiastical History (VI, 16, 1), where he describes him as a scholar who was not limited to the Hebrew texts of the Old Testament, but who was interested in the Septuagint and the Greek revisions made in the 1st-2nd centuries CE by Aquila, Symmachus and Theodotion ${ }^{26}$. Origen knows and uses all the books of the Greek Old Testament:

23 The prayer of Azariah and the Hymn of the Three Young Men in the furnace in Dan 3:25-90 and of the story of Bel and the Dragon in Dan 14:23-42.

24 Origène, Philocalie 1-20 sur les Écritures et la Lettre à Africanus sur l'histoire de Suzanne, ed. Nicholas de Lange, Sources Chrétiennes 302 (Paris: Cerf, 1983), 562-563.

25 "Il criterio adottato da Origene in EpAfr è dunque l'uso effettivo delle comunità cristiane, il che corrisponde alla sua posizione generale (Prin Praef. 2). Origene cita correntemente i deuterocanonici, ma gli capita di menzionare occasionalmente la loro assenza dal canone ebraico: così per una sezione greca di Dn $(3,25)$ e per $T b 3,1$ (Orat 14, 4; ma in Orat 11 ha citato senz'altro Tobia come Scrittura e Dn 3, 50 tra altri testi biblici, senz'alcuna riserva), o per la Sapienza di Salomone (Prin 4, 4, 6; CIo 28, 122; ma in Prin 1, 2, 5 cita e commenta Sap 7, 25-26 come Scrittura divina). Egli segnala dunque che sebbene in certi ambienti cristiani la canonicità di tali testi sia discussa, egli personalmente l'accetta" (Enrico Norelli, "Canone", in: Origene. Dizionario: la cultura, il pensiero, le opere, ed. Adele Monaci Castagno (Roma: Città Nuova, 2000), 55).

26 "Lo studio compiuto da Origene sulla parola divina fu così scrupoloso, che egli apprese anche la lingua ebraica ( $\tau \grave{\eta} \nu$ E $E \rho \alpha \ddot{i} \delta \alpha \gamma \lambda \tilde{\omega} \tau \tau \alpha \nu$ ) ed acquistò i testi originali in caratteri ebraici conservati presso gli ebrei ( $\tau \dot{\alpha} \varsigma \tau \varepsilon \pi \alpha \rho \grave{\alpha} \tau o \tilde{l} \varsigma$

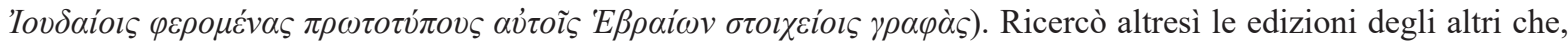

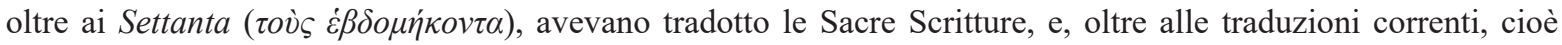
quelle di Aquila, Simmaco e Teodozione ( 
therefore there is no doubt that he also considered the book of Judith as canonical and inspired $^{27}$.

\subsection{Homily 27 on Numbers (Rufinus' Translation)}

The Homilies (O $\mu \nu \lambda i \alpha l$ ) on the book of Numbers seems to be like little treatises, which Origen draws up when he is called to preach; their Sitz im Leben and the consequent literary genre is therefore liturgical. The Homilies on Numbers have come down to us only in the Latin translation made by Rufinus (ca. 345-411 CE). According to scholars these translations enjoy absolute respect for their fidelity to the original Origenian text.

In the twenty-seventh Homily on Numbers, out of a total of twenty-eight, Origen presents a quotation from the book of Judith: "Every rational nature needs to feed on its own and suitable foods. Now, the true food of rational nature is the word of God (Cibus autem verus naturae rationabilis sermo Dei est); but, as with regard to the nourishment of the body, we have just established that there are many differences, so also the rational nature, which feeds, as we have said, on the Logos and Word of God, does not feed entirely on the one and the same Word. So, like the example of the body, also in the word of God there is a food of milk (est aliqui etiam in verb Dei cibus lactis), that is, a more open and simple doctrine (apreor scilicet simpliciorque doctrina), like that of morality, which is usually offered to beginners in divine studies (qui initia habent in divinis studiis), who receive the first elements of spiritual science. Therefore, when a certain passage of the divine books is proclaimed to them, in which nothing obscure appears, they welcome it willingly, as for example the libretto of Esther, or Judith, or even Tobias, or the precepts of Wisdom; but if, on the other hand, the book of Leviticus is read to them, the soul is immediately scandalized, and refuses any food as not its own" (Homily 27 on Numbers, 1) $)^{28}$.

Just as the body is nourished by various foods according to its capacity, so too the soul acquires ideas according to its capacity: thus, the biblical books are also to be understood in relation to the soul's capacity to appropriate them. The book of Judith is thus considered an easy-to-read biblical book, usable even by neophytes. It was likely because of its narrative style that Origen considers it a book capable of capturing the immediate interest of listeners: so, paradoxically, it is a book for neophytes. In this perspective, a deuterocanonical book like that of Judith is not relegated to a diminished status or deemed useless, but rather can delight those who want to progressively enter the mysteries of the Christian faith.

e le portò alla luce traendole fuori da non so quali nascondigli in cui erano rimaste dimenticate da lungo tempo" (Eusebio di Cesarea, Storia Ecclesiastica, ed. Franzo Migliore, vol. II (Roma: Città Nuova, 2001), 46, 32).

27 Johannes Ruwet, “Les 'Antilegomena' dans les ouevres d'Origène”, Biblica 24 (1943): 18-58, spec. 19-20 e 57-58; 23 (1942): 18.

28 Origenes, In Numeros Homilia XXVII, ed. Wilhelm Adolf Baehrens, GCS 7/1 (Leipzig: J.C. Hinrich, 1921). Origene, Omelie sui Numeri, ed. Maria Ignazia Danieli, Testi Patristici 76 (Roma: Città Nuova, 22001). 


\subsection{Homily on Judges (Rufinus' Translation)}

Even the ninth Homily on Judges was saved in the Latin translation, which Rufino made around 400 CE. Here Origen focuses on the person of Judith, in parallel with that of Debora. The latter, in her role as judge, is the protagonist together with Jael of an extraordinary victory over the Canaanite army of Sisara (cf. Jdg 4-5): "What should I say about Judith, the admirable and very noble one among all women (magnificam et omnium feminarum nobilissimam memorem)? She who, when everything was now almost lost, was not afraid to hurry alone to help, to subject even her own head to death at the hands of the barbarian Holofernes (cf. Jdt 13:1-10), and went to war not trusting in military equipment or on war horses (cf. Jdt 9:7) but on the strength of the soul and on the confidence of faith. At the same time, with determination and courage she killed the enemy, and the woman restored to the country the freedom that men had lost" (Homily on Judges IX, 1) ${ }^{29}$.

The epithets with which Origen describes Judith are very flattering: "admirable and very noble among all women"30. Here, for the first time, we can see a reference to two similar expressions in the book of Judith, in which the heroine is greeted as "blessed among all women": "Blessed are you, daughter, before the Most High God more than all women who live on earth" (Jdt 13:18; cf. 14:7). Origen recalls her deeds: the courage to challenge the enemy in total solitude (sola), the strength of spirit (in virtute animi) and the evident intimacy of faith with God (confidentia fidei). Even though the story is rooted in biblical tradition, and its historicity never questioned, Origen treats Judith and Debora typologically as an example for all believers called to fight evil.

\section{Summary}

The identification and investigation of the quotations from and allusions to the book of Judith in the writings of Clement of Alexandria and Origen allow us to shed new light on our initial questions.

From a textual point of view, both show that they know the Greek text of that book: they quote it and use it as a book that fully belongs to the canon of Christian scriptures ${ }^{31}$.

29 Origène, Homélies sur les Juges, edd. Pierre Messié, Louis Neyrand, Marcel Borret, Sources Chrétiennes 389 (Paris: Cerf, 1993), 210-212. Origene, Omelie sui Giudici. Testo della versione latina di Rufino, ed. Riccardo Pane (Bologna: Edizioni San Clemente - Edizioni Studio Domenicano, 2010), 47-49.

30 Il valore di questi epiteti è rilevato anche da Cornelius a Lapide, In librum IV Regum, I et II Paralipomenon, I et II Esdrae, Tobiae, Judith, Esther, I et II Machabaeorum, Commentaria in Scripturam Sacram t. IV (Parisiis: Ludovicus Vives, 1863), 315.

31 “Les derniers textes, s'ils n'ont pas à eux seuls une valeur absolument apodictique pour prouver que Judith, les Machabées, Dan 13 et 14 et les fragments d'Esther sont Écricture, nous disent tout au moins que l'auteur les connait, les estime et y puise comme à des sources de l'histoire juive. Mais ces sources de l'histoire juive lui sont fournies par la version grecque des Septante. Tous les livres cités avant et avec ces derniers, nous l'avons vu, sont pour Clément des livres inspirée. Pourquoi ces derniers livres ne le seraitent-ils pas comme les Septante don't ils font partie? Nous ne voyons aucune raison d'en douter. Origène qui le premier nous signale l'existence de l'opinion contraire aux deutérocanoniques, non seulement ne la partage pas, mais la réfute résolument. Dans pareilles conditions il me paraît qu'on doit supposer que tous les deutérocanoniques, même ceux de la dernière 
More precisely, Origen does not hide that he is aware of the difference between the Jewish and Christian Scriptures, but is also inclined to assert the principle of the use of the scriptures by the community; in this way, he in turn becomes the sounding board of a tradition of reading the Bible prior to him.

From the point of view of the content, we noted how the figure of Judith is completely absorbed by the allegorical and typological exegesis of Clement and Origen. In the pages of the Stromata Judith becomes the emblem of virtue ( $\left.\dot{\alpha} \rho \varepsilon \tau \eta^{\prime}\right)$ : thanks to faith in God, she bravely overcomes the test and is victorious for the good of her people. Along these lines Origen presents her as an example of how one ought to pray, as she is obedient only to God and blessed for her audacity. Any possible moral shadow thus disappears in the light of an exegesis that does not question the biblical figures, but shows them in ways that encourage the faith of believers.

\section{Bibliography}

Brooke, Alan E., and Norman McLean. The Old Testament in Greek according to the Text of the Codex Vaticanus. Vol. III/1. Cambridge, UK: Cambridge University Press, 1940.

Candido, Dionisio. Giuditta. Nuova versione, introduzione e commento. I libri biblici. Primo Testamento 32. Milano: Paoline, 2020.

Clément d'Alexandrie. Le Stromates IV, ed. Anneweis van den Hoek. Sources Chrétiennes 463. Paris: Cerf, 2001.

De Lubac, Henri. “«Origene» e «Posterità origeniana»”. In: Esegesi medievale. I quattro sensi della Scrittura. Parte prima, Volume primo, Sezione quinta: Scrittura ed Eucaristia. Opera omnia 17, 209-232. Milano: Jaca Book, ${ }^{2} 2006$.

De Lubac, Henri. “Tu m’a trompé”. In: Recherches dans la foi. Trois études sur Origène, saint'Anselme et la philosophie chrétienne. Paris: Beauchesne, 1979.

Eusèbe de Césarée. Histoire Ecclésiastique, ed. Gustave Bardy. Vol. I. Sources Chrétiennes 31. Paris: Cerf, ${ }^{31} 1993$.

Eusebio di Cesarea. Storia Ecclesiastica, ed. Franzo Migliore. Vol. II. Roma: Città Nuova, 2001.

Hanhart, Robert. Judith. Septuaginta. Vetus Testamentum Graecum Auctoritate Academiae Scientiarum Gottingensis editum. Vol. VIII/4. Göttingen: Vandenhoeck \& Ruprecht, 1979.

Hanhart, Robert. Text und Textgeschichte des Buches Judith. Mitteilungen des Septuaginta-Unternehmens 14. Göttingen: Vandenhoeck \& Ruprecht, 1979.

Norelli, Enrico. “Canone”. In: Origene. Dizionario: la cultura, il pensiero, le opere, ed. Adele Monaci, 53-60. Castagno. Roma: Città Nuova, 2000.

à Lapide, Cornelius. In librum IV Regum, I et II Paralipomenon, I et II Esdrae, Tobiae, Judith, Esther, I et II Machabaeorum. Commentaria in Scripturam Sacram. T. IV. Parisiis: Ludovicus Vives, 1863. 
Origene. Commento al Vangelo di Giovanni, ed. Vito Limone. Il Pensiero Occidentale. Milano: Bompiani, ${ }^{2} 2013$.

Origène. Homélies sur les Juges, edd. Pierre Messié, Louis Neyrand, Marcel Borret. Sources Chrétiennes 389. Paris: Cerf, 1993.

Origene. Omelie sui Giudici. Testo della versione latina di Rufino, ed. Riccardo Pane. Bologna: Edizioni San Clemente - Edizioni Studio Domenicano, 2010.

Origène. Philocalie 1-20 sur les Écritures et la Lettre à Africanus sur l'histoire de Suzanne, ed. Nicholas de Lange. Sources Chrétiennes 302. Paris: Cerf, 1983.

Origène. Homélies sur Jérémie. Homélies XII-XX et Homélies latines, edd. Pierre Husson, Pierre Nautin. Sources Chrétiennes 238. Paris: Cerf, 1977.

Origene. La preghiera, ed. Normando Antoniono. Testi Patristici 138. Roma: Citta Nuova, ${ }^{4} 2008$.

Origene. Omelie sui Numeri, ed. Maria Ignazia Danieli. Testi Patristici 76. Roma: Città Nuova, ${ }^{2} 2001$.

Origenes. Buch V-VIII gegen Celsus. Die Schrift vom Gebet, ed. Paul Koetschau. GCS 3. Leipzig: J.C. Hinrich, 1899.

Origenes. In Numeros Homilia XXVII, ed. Wilhelm Adolf Baehrens. GCS 7/1. Leipzig: J.C. Hinrich, 1921.

Patrologia Graeca 8 = Migne, Jaques Paul. Patrologiae grecae cursus completus: Clementis Alexandrini opera quae extant omnia. Tomus prior. Vol. 8. Paris: Imprimerie Catholique, 1857.

Patrologia Graeca 11 = Migne, Jaques Paul. Patrologiae grecae cursus completus: Origenis opera omnia. Tomus primus. Vol. 11. Paris: Imprimerie Catholique, 1857.

Perrone, Lorenzo. La preghiera secondo Origene. L'impossibilità donata. Brescia: Morcelliana, 2011.

Rahlfs, Alfred, Robert Hahnart. Septuaginta. Id est Vetus Testamentum graece iuxta LXX interpretes. Editio altera. Stuttgart: Deutsche Bibelgesellschaft: 2006.

Rizzi, Marco. "Introduzione”. In: Clemente di Alessandria. Gli Stromati. Note di vera filosofia, VII-LI. Milano: Paoline, 2006.

Ruwet, Johannes. "Clément d'Alexandrie, canon des Écritures et apocryphes". Biblica 29 (1948): 77-99; 240-268; 391-408.

Ruwet, Johannes. "Les «Antilegomena» dans les ouevres d'Origène”. Biblica 23 (1942): 18-42; 24 (1943): 18-58.

Simonetti, Manlio. Lettera elo allegoria. Un contributo alla storia dell'esegesi patristica. Studia Ephemeridis "Augustinianum" 23. Roma: Institutum Patristicum "Augustinianum", 1985.

Swete, Henry Barclay. The Old Testament in Greek according to the Septuagint. Vol. II, 781-814. Cambridge [UK]: Cambridge University Press, ${ }^{3} 1907$.

Stritzky, Maria-Barbara von. "Die Theologie des Gebets”. In: Origenes, Über das Gebet. Origenes Werke mit deutscher Übersetzung 21, 23-39. Berlin-Boston-Freiburg-Basel-Wien: De Gruyter-Herder, 2014. 